\title{
Unexpectedly, intense livestock grazing in arid rangelands strengthens the seedling vigor of consumed plants
}

\author{
Mariana Tadey ${ }^{1} \cdot$ Cintia P. Souto $^{1}$
}

Accepted: 28 September 2016/Published online: 20 October 2016

(C) INRA and Springer-Verlag France 2016

\begin{abstract}
Grazing intensification with non-native livestock is known to degrade vegetation cover, particularly in arid environments where low resource availability strongly limits plant recovery after damage. However, it remains unclear whether the effect of grazing on consumed plants is transmitted to plant offspring. We hypothesized that grazing would reduce fruit weight, germination percentage, and seedling vigor of consumed vegetation. Therefore, we collected mature fruits from six dominant shrub species in seven independent paddocks with increasing livestock densities. Fruits were air-dried and weighed before seed sowing. After seedling emergence, we measured the percentage of germination and seedling vigor, i.e., height and number of leaves. Hierarchical models were used to account for the effects of plant species and year of collection. Results show that, in general, increasing livestock density reduced fruit weight and percentage of germination of consumed plants. However, surprisingly, increasing livestock density enhanced seedling vigor. Overall, increasing livestock density has both negative and positive effects on consumed plants offspring.
\end{abstract}

Keywords Dryland $\cdot$ Number of leaves $\cdot$ Seedling emergence $\cdot$ Seedling height $\cdot$ Sustainable management

Mariana Tadey

mtadey@conicet.gov.ar

Cintia P. Souto

cintiap.souto@gmail.com

1 Laboratorio Ecotono, INIBIOMA-CONICET, Universidad Nacional del Comahue, Quintral 1250, 8400 Bariloche, Argentina

\section{Introduction}

In natural areas, land use intensification with grazing by nonnative livestock often reduces plant cover and diversity affecting ecological processes (Whitford 1997; Metzger et al. 2005) (Fig. 1). This effect is particularly detrimental in arid ecosystems, where low resource availability strongly limits plant recovery after damage (Schlesinger et al. 1990). Large herbivores directly damage plant tissues (Mc Naughton 1983; Tadey 2006) potentially reducing offspring production, germination, and/or seedling establishment (Edwards et al. 2005). The effect of grazing on germination and seedling establishment has been frequently studied in grasslands from mesic environments (Cornaglia et al. 2009) but is lacking for arid rangelands. In arid ecosystems, plant dynamics is different, and the impact of livestock on native vegetation offspring is less understood. Knowledge on this topic is needed, to guide adequate conservation, restoration, and management practices in highly impacted drylands.

Livestock may affect seed set, germination, and seedling establishment through several and complex mechanisms. For instance, foliar consumption either may decrease flower production and seed set (Edwards et al. 2005), or conversely may enhance flower production, compensating for damages and hence increasing seed set (Paige 1992). Livestock may also affect the quantity/quality of seeds and consequently modify plant-pollinator interactions. For example, a decrease in flower production in combination with plant isolation produced by livestock may reduce pollination frequency and/or pollen quality, affecting seed set which may make an impact on plant dynamics (Dauber et al. 2010). Other factors, such as life-form, nutrient availability, and moisture level, may influence germination and seedling growth under grazing conditions (Miller 1995; Rodríguez-Echeverría and PérezFernández 2001). In habitats with no water deficit but with 


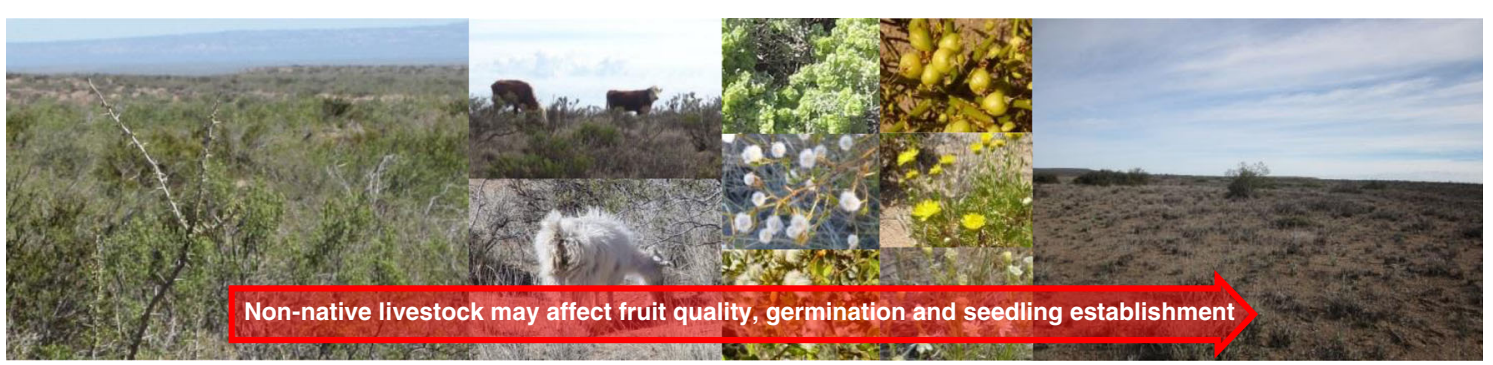

Fig. 1 Grazing by non-native livestock affects plant reproduction and offspring performances impoverishing plant cover. From left to right, this figure depicts an ungrazed paddock, non-native livestock in the study area, flowers and fruits of focal species, and a heavily grazed paddock

nutrient limitations, grazing may release competition, increasing plant isolation, generating open areas that facilitate the break of seed dormancy and increase germination (Jutila and Grace 2002; Cornaglia et al. 2009). Conversely, in arid environments, water scarcity coupled with high temperatures strongly limit plant development (Andersen and Krzywinski 2007). In these habitats, germination and seedling growth may become more dependent on facilitative plant interactions, where the standing vegetation may offer more favorable microclimatic conditions for establishment (Bisigato and Bertiller 2004).

Monte Desert is the largest and most arid biome of Southern South America; it is characterized by scattered shrubby vegetation, scarce presence of grasses, and palatable herbs, representing less than $6 \%$ of plant cover (Cabrera 1953; Tadey 2006). Like other arid regions of the world, this habitat is increasingly being used for livestock ranching. Under the hypothesis that livestock negatively affects plant offspring through maternal plant damage, offspring performance of six native dominant species from Monte Desert was studied. In response to increasing livestock density, we expected a reduction in fruit weight, germination percentage, and seedling vigor of consumed vegetation. Our results will yield suggestions to guide scientifically supported restoration and management practices for arid rangelands.

\section{Material and methods}

\subsection{Study sites, species, and collection}

The study was conducted in Neuquén province, Patagonia, Argentina $\left(39^{\circ} 17^{\prime} \mathrm{S}, 68^{\circ} 55^{\prime} \mathrm{W}\right)$. This temperate region has a mean annual precipitation of $180 \mathrm{~mm}$, a mean annual temperature of $15{ }^{\circ} \mathrm{C}$, and a mean maximum summer temperature of $29.6{ }^{\circ} \mathrm{C}$. Seven paddocks that differed in livestock density were selected for the study. They exhibited similar climatic, plant composition and edaphic characteristics. Sampling areas were located at least $300 \mathrm{~m}$ from the main road and more than $3 \mathrm{~km}$ from the house-farms. In this area, livestock grazed freely along the year, and no water point was present inside the paddocks. Livestock composition varied among paddocks. To make livestock densities comparable, they were transformed to cattle ha ${ }^{-1}$ according to Vallentine (2001), considering that 1 cow equals 1.25 horse, 0.17 goat, and 0.3 sheep. Livestock densities ranged from 0.002 to 0.038 cattle ha $^{-1}$ representing high levels of grazing pressure in the studied area (Tadey 2006). Using a counting device, a browsing index was calculated as the proportion of browsed branches and the total number of branches for each individual plant within circular 10-m diameter plots regularly separated $(30 \mathrm{~m})$ along a transect (10 plots/paddock). Browsing index was averaged by paddocks and by similar livestock density (low, intermediate, and high, see Table 1).

In order to study grazing effects on plant offspring, we collected mature fruits from six dominant shrub species that were present in all the studied paddocks: Larrea cuneifolia (Cavanilles; LC), L. divaricata (Cavanilles; LD), Monttea aphylla (Miers) Berthan et Hooker (MA), Atriplex lampa (Gillies ex Moquin) D. Dietrich (AL), Gutierrezia solbrigii (Cabrera; GS), and Grindelia chiloensis Cornel. (Cabrera; GS). This set of species have different mating systems and reproductive strategies, ranging from self-compatible generalist insectpollinated (LC, LD, GS) to self-incompatible (GC, MA) and dioecious wind pollinated species (AL) (Table 1) (Tadey et al. 2009; Tadey 2011). Fruit type and size are different among the studied plant species. Creosote bushes (Larrea sp.) have schizocarps that dehisce into five one-seeded mericarps, $M$. aphylla has fleshy, yellow, one-seeded fruits, A. lampa has utricles surrounded by two bracts, G. solbrigii has hairy achenes and $G$. chiloensis oblong achenes.

Mature fruits from 10 to 20 marked plants of each species and paddock were collected during the summer in two consecutive years. Fruits were air-dried and stored at room temperature in paper bags until next Fall after its collection (Baskin and Baskin 1998). To calculate average fruit weight per mother plant, 10 fruits per plant were weighed together using an analytical scale (Mettler AJ150, $\pm 0.00001 \mathrm{~g}$ ), before seed sowing. Residual water in the fruits was considered equal between species, because once the fruits are dry, fruit weight is mostly determined by seed weight, as the seed mass is proportionally greater than fruit mass. Achenes were directly sowed, but seeds from fleshy fruits were separated from the fleshy part, schizocarps were dehisced in mericarps, and bracts were separated from utricles before sowing. 
Table 1 List of studied plant species

\begin{tabular}{|c|c|c|c|c|}
\hline Plant species & SL & $\begin{array}{l}\text { Browsing index } \\
( \pm \mathrm{SD})\end{array}$ & Fruits/plants & $\begin{array}{l}\text { Mean fruit weight } \\
( \pm \mathrm{SD})\end{array}$ \\
\hline \multirow[t]{3}{*}{ Atriplex lampa } & $\mathrm{L}$ & $17.5(0.4)$ & \multirow[t]{3}{*}{$2098 / 224$} & \multirow[t]{3}{*}{$0.007(0.005)$} \\
\hline & I & $31.9(15.4)$ & & \\
\hline & $\mathrm{H}$ & $75.9(3.9)$ & & \\
\hline \multirow[t]{2}{*}{ Grindelia chiloensis } & $\mathrm{L}$ & $17.6(0.4)$ & \multirow[t]{2}{*}{$1038 / 107$} & \multirow[t]{2}{*}{$0.004(0.002)$} \\
\hline & I & $100(0.0)$ & & \\
\hline \multirow[t]{3}{*}{ Gutierrezia solbrigii } & $\mathrm{L}$ & $17.7(0.4)$ & \multirow[t]{3}{*}{$3468 / 360$} & \multirow[t]{3}{*}{$0.001(0.001)$} \\
\hline & I & $37.5(18.7)$ & & \\
\hline & $\mathrm{H}$ & $75.8(3.9)$ & & \\
\hline \multirow[t]{3}{*}{ Larrea cuneifolia } & $\mathrm{L}$ & $17.5(0.4)$ & \multirow[t]{3}{*}{$883 / 89$} & \multirow[t]{3}{*}{$0.020(0.006)$} \\
\hline & I & $47.4(20.0)$ & & \\
\hline & $\mathrm{H}$ & $80.0(17.4)$ & & \\
\hline \multirow[t]{3}{*}{ Larrea divaricata } & $\mathrm{L}$ & $17.5(0.5)$ & \multirow[t]{3}{*}{$1377 / 140$} & \multirow[t]{3}{*}{$0.020(0.005)$} \\
\hline & I & $40.5(19.7)$ & & \\
\hline & $\mathrm{H}$ & $76.7(3.9)$ & & \\
\hline \multirow[t]{3}{*}{ Monttea aphylla } & $\mathrm{L}$ & $17.7(0.5)$ & \multirow[t]{3}{*}{$1694 / 174$} & \multirow[t]{3}{*}{$0.070(0.020)$} \\
\hline & I & $39.4(19.4)$ & & \\
\hline & $\mathrm{H}$ & $77.9(3.5)$ & & \\
\hline
\end{tabular}

The stocking level (SL) refers to paddocks grouped by similar livestock density (low (L): 0.02-0.09 cattle ha $^{-1}$, intermediate (I): $0.014-0.015$ cattle ha $^{-1}$ and high (H): 0.031-0.038 cattle ha ${ }^{-1}$ ). Browsing index is the mean percentage of browsing, standard deviation (SD) in brackets. Fruits/plants data give the total number of fruits and plants per species. The mean fruit weight per species is given in grams with the standard deviation (SD)

\subsection{Greenhouse experiment and measurements}

In the greenhouse, ten seeds/plant were sowed in black nylon bags of $9 \mathrm{~cm}$ diameter and $15 \mathrm{~cm}$ depth filled with soil (one bag per mother plant, year of collection and species, total $=1046$ bags; 10,458 sowed seeds, averaging 1743 seeds/ species). Bags were randomly distributed in the greenhouse, where temperature varied between 18 and $28{ }^{\circ} \mathrm{C}$ over the spring-summer period and between 15 and $2{ }^{\circ} \mathrm{C}$ during autumn to winter. Seeds were watered weekly to maintain soilwater content at field capacity and facilitate germination. Germination was monitored weekly, quantifying the number of emerged seedlings over a period of 720 days, documenting date of emergence (to estimate seedling age), and measuring seedling height $(\mathrm{cm})$ and number of leaves/seedling. The objective of the experiment was to study, under greenhouse conditions, germination percentage, and seedling vigor of differently grazed species.

\subsection{Data analyses}

The effect of livestock density (independent variable) on fruit weight, germination percentage, seedling height, and number of leaves (response variables) was analyzed using hierarchical mixed effect models with lmer function, lme4 package, R 3.0.2 ( $R$ Core 2013). The relationship between germination percentage and seed size was also tested using hierarchical mixed effect models. Both analyses considered species and sampling year as random factors, and plant species identity was nested within year of collection to deal with repeated measures (Table 2). A correlation function was included in the model, without improving model fit (correlation $=$ corCompSymm $($ form $=\sim 1$ year/species)) (Zuur et al. 2009). When appropriate, a "weights" function was used to correct residual variance heterogeneity between species or year (varIdent (form $=\sim 1 \mid$ Species) or varIdent (form $=\sim 1$ year) (Zuur et al. 2009). For normalization, mean fruit weight/plant and number of leaves were transformed to natural logarithm and the percentage of germination to arcsine square root. Since livestock density is highly correlated with browsing index $\left(R^{2}=0.96, F_{1,4}=94, P<0.0006\right)$, similar results were obtained when the same models were run using the browsing index per paddock (instead of livestock density) as independent variable. Results from livestock density effects are shown as they explained the data better. Akaike information criterion (AIC) is a measure of the relative quality of statistical models for a given set of data. AIC values are reported for possible future comparisons (Zuur et al. 2009).

\section{Results and discussion}

In arid environments, grazing of non-native livestock is known to reduce plant cover and richness intensifying desertification (Tadey 2006). The present work shows that this negative effect of livestock on standing plant population also spreads through their offspring, significantly decreasing mean 
Table 2 Hierarchical regression models between livestock density (independent variable) and (1) fruit weight (lnweight); (2) germinated seeds (arcssqrgerm); (3) seedling height (height), seedling age (age) was used as fixed factor; (4) number of leaves (lnleaves), seedling age and height were used as fixed factors; (5) hierarchical regression model between fruit weight (independent variable) and the number of germinated seeds (arcssqrgerm)

\begin{tabular}{|c|c|c|c|c|c|c|}
\hline $\begin{array}{l}\text { Dependent variable } \\
\text { (transformation) }\end{array}$ & Mixed model & AIC & $\begin{array}{l}\text { Independent } \\
\text { variable }\end{array}$ & $d f$ & $t$ value & $P$ value \\
\hline $\begin{array}{l}\text { 1) Fruit weight } \\
\text { (ln) }\end{array}$ & $\begin{array}{l}\text { lnweight } \sim \text { livestock, random }=\sim 1 \text { year/ } \\
\text { species weights }=\text { varIdent } \\
(\text { form }=\sim 1 \text { year })\end{array}$ & 893 & Livestock & 1046 & -3.02 & 0.00260 \\
\hline $\begin{array}{l}\text { 2) Germinated seeds } \\
\text { (Arcsine square root) }\end{array}$ & $\begin{array}{l}\text { arcssqrgerm } \sim \text { livestock }+ \text { lnweight } \\
\text { random }=\sim 1 \mid \text { year } / \text { species } \\
\text { weights }=\text { varIdent }(\text { form }=\sim 1 \mid \text { Species })\end{array}$ & 2.15 & $\begin{array}{l}\text { livestock } \\
\text { lnweight }\end{array}$ & 350 & $\begin{array}{l}-3.19 \\
-4.34\end{array}$ & $\begin{array}{l}0.00150 \\
<0.00001\end{array}$ \\
\hline 3) Seedling height & $\begin{array}{l}\text { height } \sim \text { livestock }+ \text { age }+ \text { lnweight, } \\
\text { random }=\sim 1 \text { year } / \text { species } \\
\text { weights }=\text { varIdent (form }=\sim 1 \mid \text { Species })\end{array}$ & 1572 & $\begin{array}{l}\text { livestock } \\
\text { age } \\
\text { lnweight }\end{array}$ & 275 & $\begin{array}{l}2.44 \\
4.26 \\
2.04\end{array}$ & $\begin{array}{l}0.01500 \\
<0.00001 \\
0.04200\end{array}$ \\
\hline $\begin{array}{l}\text { 4) Number of leaves } \\
\text { (ln) }\end{array}$ & $\begin{array}{l}\text { lnleaves } \sim \text { livestock }+ \text { age }+ \text { lnweight }+ \text { - } \\
\text { height, random }=\sim 1 \mid \text { year } / \text { species } \\
\text { weights }=\text { varIdent }(\text { form }=\sim 1 \mid \text { Species })\end{array}$ & 469 & $\begin{array}{l}\text { livestock } \\
\text { age } \\
\text { lnweight } \\
\text { height }\end{array}$ & 267 & $\begin{array}{l}2.49 \\
5.26 \\
2.12 \\
18.2\end{array}$ & $\begin{array}{l}0.01300 \\
<0.00001 \\
0.03500 \\
<0.00001\end{array}$ \\
\hline $\begin{array}{l}\text { 5) Germination rate } \\
\text { (Arcsine square root) }\end{array}$ & $\begin{array}{l}\text { arcssqrgerm } \sim \text { lnweight } \\
\text { random }=\sim 1 \mid \text { species weights }=\text { varIdent } \\
(\text { form }=\sim 1 \mid \text { Species })\end{array}$ & -1.6 & Lnweight & 355 & 2.27 & 0.02400 \\
\hline
\end{tabular}

The natural logarithm of fruit weight was used as fixed factor in all regressions. The number of germinated seeds was transformed to arcsine square root (arcssqrgerm). Plant species (random factor) was nested in the year of collection to control for repeated measures. When appropriate, a "weights" function was used to correct residual variance heterogeneity between species or year. All regressions were performed under normal probability distribution. Akaike information criterion (AIC) is a measure of the relative quality of statistical models for a given set of data

fruit weight (Table 2, $N=1059$; Fig. 2a, white symbols and dashed line) and germination percentage (Table 2, $N=362$, Fig. 2a, black symbols and solid line). There is a drop in fruit weight under high but not highest livestock density (Fig. 2a). However, when averaging both treatments, there is a fruit weight reduction of $30 \%$ compared with paddocks with low livestock density showing a general decreasing trend (Fig. 2a). Several mechanisms may explain this reduction. For instance, foliar damage on plants may directly produce an impact on the energy available for fruit formation reducing the quantity and/ or quality (e.g., weight) of the offspring (Whitham et al. 1991). Since, in studied species, seed weight represents the major component of fruit weight (Tadey 2007), low fruit weight may reflect insufficient reserves in their endosperm affecting germination and plant development (Zaidman et al. 2010). Alternatively, livestock may increase plant isolation decreasing pollination levels (i.e., pollen quantity) or pollen quality (i.e., endogamic pollen) resulting in poor fruit quality (Ramsey and Vaughton 2000; Tadey 2008; Yoshihara et al. 2008). Within each species, heavier fruits from less grazed paddocks (Fig. 3, black symbols) significantly germinated more than lighter fruits from heavily grazed paddocks (Fig. 3, white symbols; Table 2). Several studies have suggested that seed mass may be a character under maternal control, which, in turn, is affected by environmental conditions (Temme 1986). Therefore, maternal plants growing in benign environments are expected to produce larger seeds with increased germination and seedling size (Temme 1986).
Regardless of the underlying mechanisms involved, the observed results suggest that increasing livestock density reduces fruit weight and germination percentage.

Fruit weight varied significantly among studied species. Species with smaller fruits (Table 1) germinated more than species with higher fruit weight (Table 2, Fig. 3). The three studied species with higher fruit weight, such as Larrea divaricata, L. cuneifolia, and M. aphylla, showed scarce germination (Fig. 3). Both Larrea species have a deep physiological dormancy, requiring complex pre-germination treatments for dormancy breaking (Baskin and Baskin 1998) and still with those treatments they have low germination rates ( $20 \%$ ) (Barbour 1968; Bonvissuto and Busso 2007). Yet, most of the optimal germination requirements of the studied species are not fully understood and demand further investigation. Although this information is relevant, the aim of this study was to analyze the effect of increasing livestock density on the offspring performance of consumed vegetation, under greenhouse conditions.

The reproductive strategies of individual species may also determine the effect of livestock on plant offspring performance. Self-incompatible species, that obligatory depend on pollinators, should be more affected than wind and selfpollinated species due to increased plant isolation and/or impact on pollinator community caused by livestock (Tadey 2008, 2015). Wind pollinated species may be even favored in open areas, increasing pollen mobility (Culley et al. 2002). This was partially supported by our results as two of 

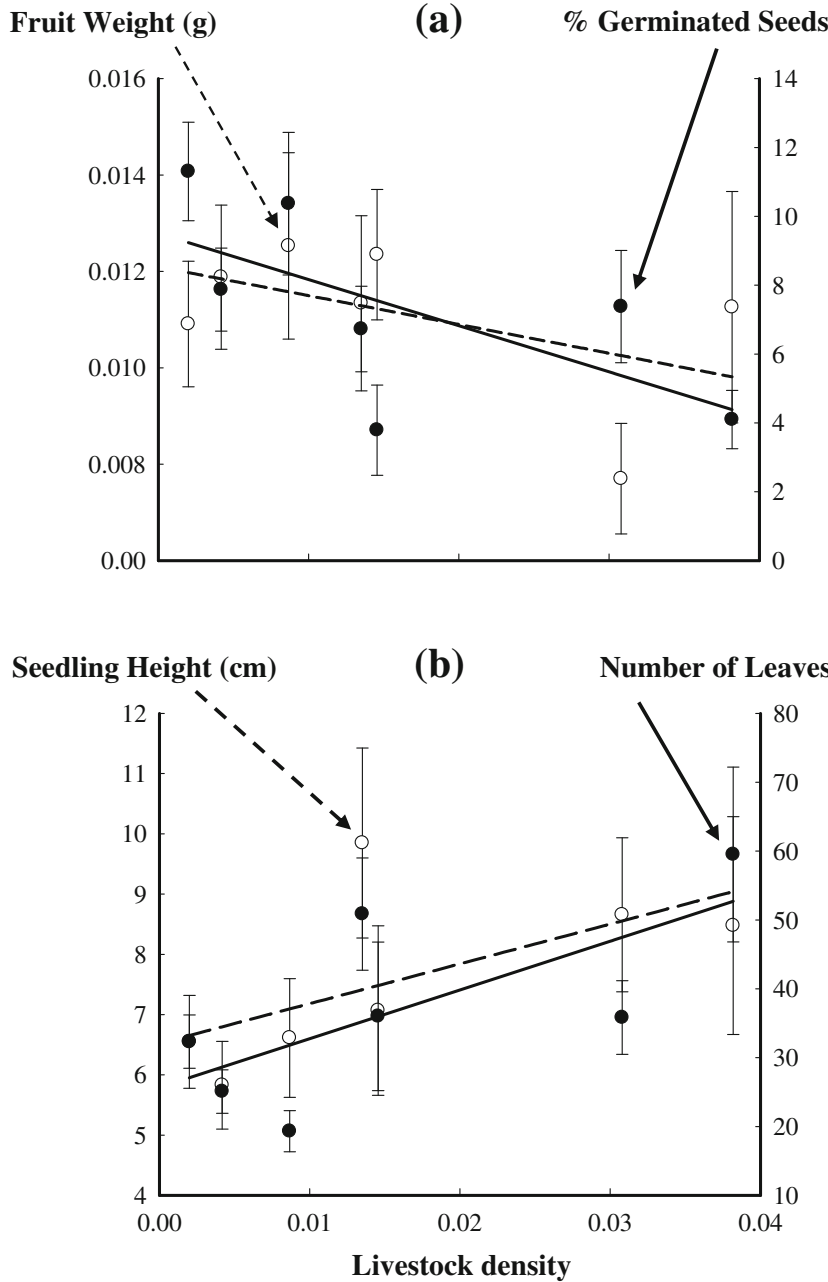

Fig. 2 Relationships between livestock density (cattle ha ${ }^{-1}$ ) vs (a) mean $( \pm \mathrm{SE})$ fruit weight (open symbols and dashed line) and percentage of germinated seeds (closed symbols and solid line); (b) mean seedling height (open symbols and dashed line) and number of leaves/seedling (closed symbols and solid line). Mean values were averaged across all studied plant species (Atriplex lampa, Grindelia chiloensis, Gutierrezia solbrigii, Larrea cuneifolia, Larrea divaricata, and Monttea aphylla)

the studied self-incompatible species showed a reduction in germination percentage between extreme livestock densities. M. aphylla decreased from 20.9 to $10 \%$ and G. chiloensis, decreased from 32.5 to $14.6 \%$ between low and intermediate livestock densities. A previous study showed a significantly reduced fructification of $G$. chiloensis in highly grazed paddocks $\left(r=-0.99, R^{2}=0.99 ; P=0.01\right.$ (Tadey 2007)) impeding germination estimation on this species. A. lampa, the only anemophilous species studied, showed similar germination percentage between extreme livestock densities $(\sim 34 \%)$. This highlights the importance of considering reproductive strategies when developing restoration and management plans for rangeland sustainability.

The combined effect of livestock pressures and species strategies may also have consequences on seedling vigor and development (Baskin and Baskin 1998). As expected,

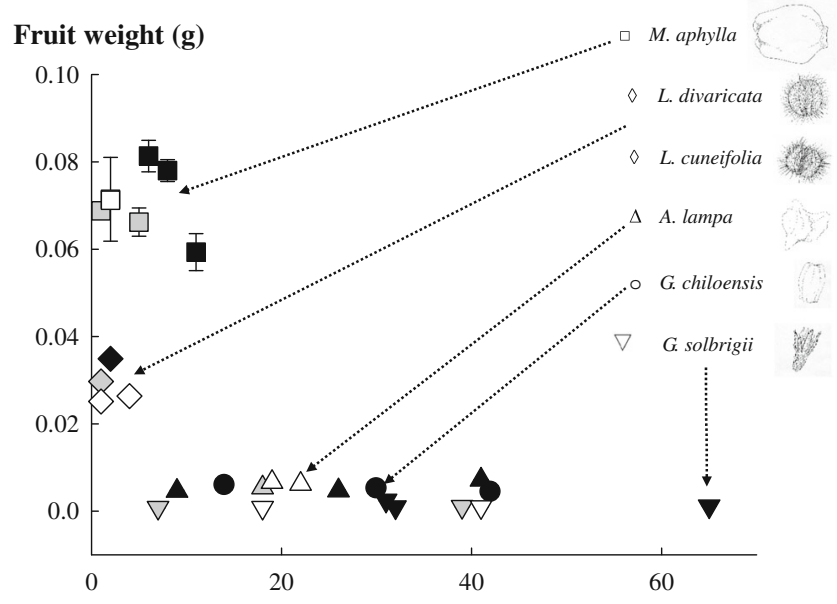

Total number of germinated seeds

Fig. 3 Relationship between mean fruit weight ( \pm SE) and total number of germinated seeds. Symbol color depicts categorical stocking intensity (i.e., similar levels of livestock density): white = high; gray=intermediate; black $=$ low. Plant species are coded by the following symbols: square $=$ Monttea aphylla , diamond $=$ Larrea $\mathrm{spp}$, triangle up $=$ Atriplex lampa, circle $=$ Grindelia chiloensis, triangle down $\mathrm{spp},=$ Gutierrezia solbrigii. Species are ordered in the legend by decreasing fruit weight

seedling vigor was positively associated with fruit weight and seedling age $(\mathrm{t}$ weight, leaves $=2.12, P=0.035 ; \mathrm{t}$ age, height $=4.26, P<0.0001 ; \mathrm{t}$ weight, height $=2.04, P=0.04 ; \mathrm{t}$ age, leaves $=5.26, P<0.0001$, respectively). Additionally, taller seedlings developed more leaves than shorter ones ( $\mathrm{t}$ height, leaves $=18.2, P<0.00001)$, and the number of leaves and seedling height were not associated with the number of seedlings/ pot $\left(\mathrm{F}_{\text {leaves }}=-0.04, P=0.60 ; \mathrm{F}\right.$ height $\left.=-0.06, P=0.46\right)$. Unexpectedly, smaller fruits from highly grazed paddocks produced seedlings more vigorous than fruits from paddock with low livestock density. Seedling vigor, measured as seedling height and number of leaves, increased with livestock density (Table 2; Fig. 2b). These contra-intuitive results are consistent with the environmental maternal effect hypothesis, which predicts enhanced offspring development in response to environmental stress endured by maternal plants (Hereford and Moriuchi 2005). However, maternal environmental effects may also be transmitted by changes in seed biochemistry and/or epigenetic changes that persist through generations modifying offspring phenotypes and performance (Herman and Sultan 2011). This trans-generational adaptive plasticity is a key component of plant evolutionary dynamics (Zas et al. 2013). Restoration and management plans should consider this offspring plasticity to enhance rangeland sustainability.

Since seedling phase is a very vulnerable period in plant life cycle, our results suggest that smaller seeds (from heavily grazed paddocks) generating more vigorous seedlings might be good candidates to improve plant cover in degraded areas. However, grazing might reduce genetic variation of the population by selecting individual plants with this particular phenotype. These selective pressures might jeopardize future plant 
species responses to expected scenarios of climate change or other unexpected stressful conditions (van Tienderen 2000). Also, the lower germination capacity of these smaller seeds may complicate restoration practices because more seeds will be necessary to reach a desired plant cover, and fruiting plants are difficult to find in heavily grazed paddocks. Conversely, restoration practices may take advantage of seeds from less grazed paddocks since they are more abundant and bigger; they germinate more and they might hold higher levels of genetic variation than those from heavily grazed paddocks.

\section{Conclusion}

Ecological studies on germination, seedling vigor, and establishment are important to the sustainability of arid rangelands. This work shows that increasing livestock density simultaneously has negative and positive effects on the quantity/ quality of consumed plants offspring. Smaller seeds from heavily grazed paddocks, producing seedlings, which are more vigorous, are good candidates to restore plant cover in degraded arid rangelands. However, including heavier seeds from lightly grazed paddocks, higher germination percentage is suggested for sustainable agriculture. A combination of both types of seeds would improve the recovery capacity of poorly resilient arid rangelands.

Acknowledgments We thank A. G. Farji-Brener, J. Franzese, N. Tadey, and J. C. Tadey. This work was partially supported PIP2011 IU D750 and PICT2011-1578 (SECYT - CONICET, Argentina).

\section{References}

Andersen GL, Krzywinski K (2007) Mortality, recruitment and change of desert tree populations in a hyper-arid environment. PLoS One 2, e208. doi:10.1371/journal.pone.0000208

Barbour MG (1968) Germination requirements of the desert shrub Larrea divaricata. Ecology 49:915-923. doi:10.2307/1936543

Baskin C, Baskin J (1998) Seeds. Ecology, biogeography, and evolution of dormancy and germination. San Diego, CA, US

Bisigato AJ, Bertiller MB (2004) Seedling recruitment of perennial grasses in degraded areas of the Patagonian Monte. J Range Manag 57:191. doi:10.2307/4003918

Bonvissuto GL, Busso CA (2007) Germination of grasses and shrubs under various water stress and temperature conditions. (International Journal of Experimental Botany) 76:119-131

Cabrera A (1953) Esquema fitogeográfico de la República Argentina. Rev Mus La Plata, Botánica 8:87-168

Cornaglia PS, Schrauf GE, Deregibus VA (2009) Flooding and grazing promote germination and seedling establishment in the perennial grass Paspalum dilatatum. Aust Ecol 34:343-350. doi:10.1111 /j.1442-9993.2009.01935.x/full

Culley TM, Weller SG, Sakai AK (2002) The evolution of wind pollination in angiosperms. Trends Ecol Evol 17:361-369. doi:10.1016 /S0169-5347(02)02540-5

Dauber J, Biesmeijer JC, Gabriel D et al (2010) Effects of patch size and density on flower visitation and seed set of wild plants: a pan-
European approach. J Ecol 98:188-196. doi:10.1111/j.13652745.2009.01590.x

Edwards GR, Hay MJM, Brock JL (2005) Seedling recruitment dynamics of forage and weed species under continuous and rotational sheep grazing in a temperate New Zealand pasture. Grass Forage Sci 60: 186-199. doi:10.1111/j.1365-2494.2005.00467.x

Hereford J, Moriuchi KS (2005) Variation among populations of Diodia teres (Rubiaceae) in environmental maternal effects. J Evol Biol 18: 124-131. doi:10.1111/j.1420-9101.2004.00797.x

Herman JJ, Sultan SE (2011) Adaptive transgenerational plasticity in plants: case studies, mechanisms, and implications for natural populations. Front Plant Sci 2:102. doi:10.3389/fpls.2011.00102

Jutila HM, Grace JB (2002) Effects of disturbance on germination and seedling establishment in a coastal prairie grassland: a test of the competitive release hypothesis. J Ecol 90:291-302. doi:10.1046/j.13652745.2001.00665.x

Mc Naughton SJ (1983) Compensatory plant growth as a response to herbivory as a response to herbivory compensatory plant growth. Oikos 40:329-336

Metzger KL, Counghenour MB, Reich RM, Boone RB (2005) Effects of seasonal grazing on plant species diversity and vegetation structure in a semi-arid ecosystem. J Arid Environ 61:147-160. doi:10.1016 /j.jaridenv.2004.07.019

Miller MF (1995) Acacia seed survival, seed germination and seedling growth following pod consumption by large herbivores and seed chewing by rodents. Afr J Ecol 33:194-210. doi:10.1111/j.13652028.1995.tb00797.x

Paige KN (1992) Overcompensation in response to mammalian herbivory: from mutualistic to antagonistic interactions. Ecology 73:20762085. doi: $10.2307 / 1941456$

R Core T (2013) R Development Core Team (2013). R: A language and environment for statistical computing. R Foundation for Statistical Computing, Vienna, Austria. ISBN 3-900051-07-0, http://www.Rproject.org

Ramsey M, Vaughton G (2000) Pollen quality limits seed set in Burchardia umbellata (Colchicaceae). Am J Bot 87:845-852. doi: $10.2307 / 2656892$

Rodríguez-Echeverría S, Pérez-Fernández MA (2001) Light and nutrients availability determine seeds germination in five perennials. $J$ Mediterr Ecol 2:83-91

Schlesinger WH, Reynolds JF, Cunningham GL et al (1990) Biological feedbacks in global desertification. Science 247:1043-1048. doi:10.1126/science. 247.4946 .1043

Tadey M (2006) Grazing without grasses: effects of introduced livestock on plant community composition in an arid environment in northern Patagonia. Appl Veg Sci 9:109-116. doi:10.1111/j.1654-109 X.2006.tb00660.x

Tadey M (2007) Efectos del pastoreo sobre la polinización y producción de semillas en el Monte del NO Patagónico. PhD Thesis PhD:263

Tadey M (2008) Efecto del ganado sobre los niveles de polinización en especies vegetales del monte patagónico. Ecol Aust 18:89-100. doi: $10.2307 / 1479000$

Tadey M (2011) Reproductive biology of Monttea aphylla (Scrophulariaceae). Aust J Bot 59:713-718. doi:10.1071/BT10282

Tadey M (2015) Indirect effects of grazing intensity on pollinators and floral visitation. Ecol Entomol 40:451-460. doi:10.1111/een.12209

Tadey M, Tadey JC, Tadey N (2009) Reproductive biology of five native plant species from Monte desert of Argentina. Bot J Linn Soc 161: 190-201. doi:10.1111/j.1095-8339.2009.01001.x

Temme DH (1986) Seed size variability: a consequence of variable genetic quality among offspring? Evolution 40:414-417. doi:10.2307 12408819

Vallentine JF (2001) Grazing management. Academic, San Diego

van Tienderen PH (2000) Elasticities and the link between demographic and evolutionary dynamics. Ecology 81:666-679. doi:10.1890 /0012-9658(2000)081[0666:EATLBD]2.0.CO;2] 
Whitford W (1997) Desertification and animal biodiversity in the desert grasslands of North America. J Arid Environ 37:709-720. doi:10.1006/jare.1997.0313

Whitham TG, Maschinski J, Larson KC, Paige KN (1991) Plant responses to herbivory: the continuum from negative to positive and underlying physiological mechanisms. In: Price PW, Lewinsohn TM, Fernandes GW, Benson WW (eds) Plant-animal interactions: evolutionary ecology in tropical and temperate regions. Wiley, J. and Sons, Inc, New York, pp 227-256

Yoshihara Y, Chimeddorj B, Buuveibaatar B et al (2008) Effects of livestock grazing on pollination on a steppe in eastern Mongolia. Biol Conserv 141:2376-2386. doi:10.1016/j.biocon.2008.07.004
Zaidman BZ, Ghanim M, Vaknin Y (2010) Effect of seed weight on seed vigour and early seedling growth of Jatropha curcas, a biodiesel plant. Seed Sci Technol 38:757-766

Zas R, Cendán C, Sampedro L (2013) Mediation of seed provisioning in the transmission of environmental maternal effects in Maritime pine (Pinus pinaster Aiton). Heredity (Edinb) 111:248-255. doi:10.1038 /hdy.2013.44

Zuur AF, Ieno EN, Walker NJ, et al. (2009) Mixed effects models and extensions in ecology with R, Statistics for biology and health. Springer Science + Business Media, LLC New York, USA, pp 550 